\title{
DESCRIPTION OF MATHEMATICS REASONING ABILITY IN SOLVING STORY QUESTIONS BASED ON COGNITIVE STYLES AND INITIAL ABILITY OF STUDENTS
}

\author{
Mutmainnah $^{1)}$, Usman Mulbar ${ }^{2)}$, Djadir $^{3)}$ \\ ${ }^{1}$ Prodi Pendidikan Matematika PPs UNM \\ ${ }^{2,3}$ Universitas Negeri Makassar \\ e-mail : mutmainnahnas@gmail.com
}

\begin{abstract}
This study is descriptive research which employs qualitative approach, aims at describing Mathematics reasoning ability in solving story questions based on cognitive style and initial ability of students. The cognitive styles examined are Field Independent (FI) and Field Dependent (FD). Where as, initial ability of students are categorized as high and low. The research site was at MtsN 1 Makassar City with 8 students of grade VIII as the research subjects. The research subjects represented four categories, namely (1) FI with high initial ability, (2) FI with low initial ability, (3) FD with high initial ability and (4) FD with low initial ability. Data collection techniques were conducted through interview based on mathematics reasoning ability test. The research instruments were Group Embedded Figure Test (GEFT), initial ability test, mathematics reasoning ability test, and interview guidance which were valid and reliable. The results of the study reveal that: (1) FI subjects with high initial ability has a good reasoning level in understanding the structure in solving mathematics problems, (2) FD subjects with high initial ability has minor problems in understanding the structure when solving rectangular story questions but still able to arise his reasoning ability, (3 ) FI subjects with low initial ability has reasoning ability but inaccurate in conducting solution plan, and (4) FD subjects with low initial ability has less reasoning ability so that they need guidance in solving rectangular story questions.
\end{abstract}

Keywords: reasoning ability, cognitive style, initial ability, rectangular story Questions

\section{PENDAHULUAN}

Matematika merupakan ilmu dasar yang menunjang peranan penting dalam perkembangan ilmu pengetahuan dan teknologi. Salah satu fungsi matematika yaitu untuk mengembangkan kemampuan bernalar melalui kegiatan penyelidikan, eksplorasi, dan eksperimen. Dalam pembelajaran matematika, kemampuan penalaran berperan baik dalam penyelesaian masalah. Termasuk dalam kehidupan sehari-hari, kemampuan bernalar dapat digunakan pada saat menyelesaikan masalah-masalah yang terjadi.Depdiknas dalam Shadiq (2004) menyatakan bahwa "Materi matematika dan penalaran matematis merupakan dua hal yang tidak dapat dipisahkan, yaitu materi matematika dipahami dalam penalaran dan penalaran dipahami dan dilatihkan melalui belajar materi matematika". Karena adanya dua hal yang saling berkaitan antara matematika dan penalaran matematis, maka sangat penting dalam pembelajaran matematika menekankan pentingnya kemampuan penalaran matematis.

Penalaran merupakan suatu kegiatan atau proses berpikir untuk menarik kesimpulan atau membuat suatu pernyataan baru yang benar berdasarkan 
pernyataan yang kebenarannya telah dibuktikan sebelumnya. Adapun penalaran matematis yaitu proses berpikir dalam menarik kesimpulan berupa pengetahuan baru berdasarkan logika dan bersifat analitik yang didukung oleh argumen matematis berdasarkan pernyataan yang diketahui kebenarannya.

Indikator penalaran matematika dalam penelitian ini adalah:

1) Menyajikan pernyataan matematika secara lisan, tertulis atau gambar.

2) Mengajukan dugaan;

3) Melakukan manipulasi matematika;

4) Menyusun bukti dan memberikan alasan terhadap kebenaran solusi;

5) Menarik kesimpulan dari pernyataan;

6) Memeriksa kesahihan suatu argumen;

Berdasarkan hasil penelitian yang dilakukan oleh Muharom (2014) yang menyatakan bahwa kemampuan penalaran matemastis siswa masih kurang dikembangkan dengan baik. Selanjutnya, Permana dan Sumarmo (2007) berpendapat bahwa kemampuan penalaran matematis siswa melalui pembelajaran biasa tergolong kurang. Oleh karena itu, peneliti mengidentifikasi bahwa kemampuan penalaran matematis siswa masih rendah.

Salah satu kemampuan matematika yang ada pada diri siswa adalah kemampuan untuk menyelesaikan soal cerita. Soal cerita matematika adalah soal yang disajikan dalam bentuk kalimat sehari-hari dan umumnya merupakan aplikasi dari konsep matematika yang dipelajari. Penerapan (aplikasi) adalah proses berpikir yang setingkat lebih tinggi dari pemahaman. Dalam mengaplikasikan matematika siswa diharapkan mampu memilih, menggunakan dan menerapkan dengan tepat suatu teori, hukum, metode pada situasi baru atau situasi yang lain (Usman, 1993). Menyelesaikan soal cerita yang berkaitan dengan masalah kehidupan sehari-hari dapat melatih dan membiasakan siswa menggunakan kemampuan penalarannya karena dalam menyelesaikan masalah soal cerita dibutuhkan langkah-langkah penyelesaian yang memerlukan pemahaman dan penalaran. Namun kenyataannya, banyak siswa yang mengalami kesalahan dalam menyelesaikan soal cerita. Seperti yang dibahas dalam penelitian Erna Hartika Wati (2016) yang menyatakan bahwa diperoleh 4 jenis kesalahan dan besar presentase untuk setiap jenis kesalahan dalam menyelesaiakan soal cerita yaitu kesalahan pemahaman 55,50\%, kesalahan transformasi $27,75 \%$, kesalahan keterampilan proses 6,28\% dan kesalahan encoding 10,47\%. Hasil menunjukkan kesalahan pemahaman dan kesalahan transformasi lebih dominan dibandingkan kesalahan lainnya. Secara umum faktor penyebab kesalahan adalah kemampuan penalaran dan kreativitas siswa yang rendah dalam menyelesaikan masalah konteks nyata dan memanipulasinya ke dalam bentuk aljabar.

Menurut Mulbar (2012) matematika harus dekat dengan siswa dan relevan dengan kehidupan nyata sehari-hari oleh karena itu siswa perlu dilatih menerapkan kembali konsep matematika yang telah dimiliki siswa pada kehidupan sehari-hari. Salah satu cara melatih penerapan konsep matematika pada kehidupan sehari-hari adalah dengan memberikan soal cerita untuk dikerjakan. Siswa diharapkan dapat menerjemahkan kata-kata dalam soal cerita tersebut, melakukan kalkulasi dan menggunakan prosedur-prosedur relevan yang telah dipelajarinya. Soal cerita melatih siswa berpikir secara analisis, melatih 
kemampuan menggunakan tanda operasi hitung (penjumlahan, pengurangan, perkalian dan pembagian) serta melatih kemampuan penalarannya.

Seperti yang telah dijelaskan di atas yaitu dalam menyelesaikan soal cerita matematika dibutuhkan kemampuan penalaran matematis. Kemampuan penalaran matematis ini dipengaruhi oleh beberapa fakor diantaranya yaitu gaya kognitif dan kemampuan awal siswa.

Cara berpikir siswa dapat dilihat dari cara siswa menyampaikan pesan, baik berupa ide, pendapat, pertanyaan, maupun pernyataan. Namun kita ketahui bahwa secara alamiah kebiasaan siswa yang terdapat pada diri mereka dan cenderung konsisten dalam berpikir, memperhatikan, berpendapat, mengingat, dan menyelesaikan masalah pasti berbeda antara siswa satu dengan siswa lainnya. Hal ini mengakibatkan adanya perbedaan pada setiap siswa dalam menerima dan mengolah informasi atau konsep pelajaran yang diberikan guru. Siswa memiliki caranya sendiri dalam menyusun informasi yang dilihat, diingat, dan dipikirkannya sesuai dengan keinginannya. Adanya perbedaan siswa yang terdapat dalam cara menyusun dan mengelola informasi serta pengalamanpengalaman tersebut dikenal dengan gaya kognitif. Perbedaan ini tentunya akan memberikan dampak terhadap kemampuan mengkonstruksi pengetahuan siswa dalam memahami dan mengolah informasi yang diperoleh untuk kemudian digunakan dalam menyelesaikan masalah matematika.

Ada beberapa pengertian tentang gaya kognitif (cognitive style) yang dikemukakan oleh beberapa ahli, namun pada prinsipnya pengertian tersebut relatif sama. Diantaranya yaitu menurut Witkin dalam Susanto (2008) gaya kognitif merupakan karakteristik setiap individu dalam menggunakan fungsi kognitif yang ditampilkan melalui kegiatan persepsi dan intelektual secara konsisten. Selain itu Mulbar, dkk (2017) menyatakan bahwa:

Cognitive style refers to the way people obtain information and use strategies for responding to an assignment. It is known as style and not as ability, because it refers to how people process information and solve problems, and does not refer to the best method.

Pernyataan di atas dapat diartikan bahwa gaya kognitif mengacu pada cara orang memperoleh informasi dan menggunakan strategi untuk merespon suatu tugas. Disebut sebagai gaya kognitif dan bukan sebagai kemampuan karena merujuk pada bagaimana seseorang memperoleh informasi serta memecahkan masalah, dan bukannya mengacu pada bagaimana seseorang untuk memperoleh cara yang terbaik dalam memproses informasi dan memecahkan masalah.

Banyak ahli yang membedakan jenis gaya kognitif namun gaya kognitif Field Dependent (FD) dan Field Independent (FI) yang dikemukakan oleh Witkin akan menjadi fokus pada penelitian ini. Seseorang dikatakan mempunyai gaya kognitif field dependent jika seseorang lebih menyukai belajar kelompok, sangat dipengaruhi oleh lingkungan, dan memungkinkan mencapai tujuan belajar melalui motivasi ekstrinsi. Sedangkan seseorang dikatakan mempunyai gaya kognitif field independent jika seseorang lebih menyukai belajar secara individual, kurang 
dipengaruhi oleh lingkungan, dan memungkinkan mencapai tujuan belajar melalui motivasi intrinsik. Mereka memandang keadaan sekitarnya lebih secara analitis.

Perbedaan proses bernalar siswa field dependent dan field independent akan terlihat saat menyelesaikan soal-soal matematika, terutama soal cerita matematika karena soal cerita matematika adalah soal-soal matematika yang menggunakan bahasa verbal yang umumnya berhubungan dengan kegiatan seharihari dan membutuhkan penalaran dalam menyelesaikannya.

Kemampuan awal adalah semua pengetahuan yang telah ada dalam otak pembelajar sebelum mereka mempelajari pengetahuan baru dan akan mempengaruhi proses pembelajaran baru tersebut. Kemampuan awal merupakan prasyarat yang diperlukan untuk mengikuti pembelajaran berikutnya agar dalam pembelajaran tersebut dapat berlangsung lancar. Setiap siswa mempunyai kemampuan awal yang berbeda-beda, oleh karena itu cepat lambatnya siswa dalam menguasai materi pelajaran matematika dipengaruhi oleh tingkat kemampuan awal. Dalam pembelajaran matematika, guru perlu memperhatikan kemampuan awal siswa dalam meningkatkan kemampuan penalaran matematis siswa. Ketika siswa diberi bab baru pada materi matematika maka siswa tersebut akan berusaha memahami materi itu dengan cara mengingat pengetahuan dari materi matematika sebelumnya, kemudian materi tersebut akan dihubungkan dengan materi baru melalui ide-ide siswa.

Dalam menyelesaikan masalah matematika banyak hal yang perlu diperhatikan karena materi-materi yang terdapat pada pelajaran matematika tersusun secara sistematis dan konsep matematika yang satu dengan yang lainnya saling berkaitan membentuk satu konsep baru yang lebih kompleks. Kemungkinan siswa tidak dapat menyelesaikan masalah matematika dan menggunakan kemampuan penalarannya karena tingkat kemampuan awal matematika siswa yang masih kurang. Siswa harus dapat menghubungkan apa yang telah dimiliki dalam struktur berpikirnya berupa konsep matematika, dengan permasalahan yang dia hadapi. Oleh karena itu agar dapat mengoptimalkan kemampuan penalaran matematis siswa dalam menyelesaikan masalah matematika dengan mudah khususnya masalah matematika yang berkaitan dengan soal cerita diperlukan kemampuan awal yang baik.

Berdasarkan uraian permasalahan di atas, penulis akan melakukan penelitian dengan topik "Deskripsi Kemampuan Penalaran Matematis dalam Menyelesaikan Soal Cerita Ditinjau dari Gaya Kognitif dan Kemampuan Awal Siswa".

\section{METODE PENELITIAN}

Penelitian ini adalah penelitian deskriptif dengan menggunakan pendekatan kualitatif. Subjek dalam penelitian ini dipilih dari siswa kelas VIII.1 MTsN 1 Kota Makassar tahun pelajaran 2018/2019. Subjek penelitian terdiri dari delapan siswa dengan rincian masing-masing dua siswa pada tiap kategori gaya kognitif Field Independent berkemampuan awal tinggi, Field Independent berkemampuan awal rendah, Field Dependent berkemampuan awal tinggi dan Field Dependent berkemampuan awal rendah. Penetapan subjek penelitian juga mempertimbangkan kemampuan komunikasi yang baik. 
Data penelitian dikumpulkan menggunakan dua instrumen yakni: 1) instrumen utama yaitu peneliti sendiri; dan 2) instrumen pendukung terdiri dari:a) Group Embedded Figures Test (GFFT) yang dimodifikasi oleh Witkin (1973); b) Tes kemampuan awal; c) Tes kemampuan penalaran matematis dan d) pedoman wawancara. Untuk menguji kredibilitas data (kepercayaan terhadap data), peneliti melakukan triangulasi metode. Dalam penelitian ini analisis secara keseluruhan akan dilakukan dengan langkah-langkah sebagai berikut: reduksi data, tahap penyajian data dan penarikan kesimpulan.

\section{HASIL PENELITIAN DAN PEMBAHASAN}

Berdasarkan hasil tes gaya kognitif GFFT dan tes kemampuan awal diperoleh data seperti yang tertera pada Tabel 1 .

\section{Tabel 1. Hasil Pengkategorian Gaya Kognitif dan Kemampuan Awal Siswa}

\begin{tabular}{lc}
\hline \multicolumn{1}{c}{ Kategori Gaya Kognitif } & Kelas VIII.1 \\
\hline Field independent berkemampuan awal tinggi & 11 \\
(FIT) & 8 \\
Field independent berkemampuan awal rendah & 3 \\
(FIR) & 8 \\
Field dependent berkemampuan awal tinggi (FDT) & \\
Field dependent berkemampuan awal rendah & \\
(FDR) & \\
\hline
\end{tabular}

Dari empat kategori di atas yaitu Field independent berkemampuan awal tinggi (FIT), Field independent berkemampuan awal rendah (FIR), Field dependent berkemampuan awal tinggi (FDT) dan Field dependent berkemampuan awal rendah (FDR) dipilih masing-masing dua siswa. Subjek penelitian juga dipilih berdasarkan pada beberapa kriteria seperti subjek dapat berkomunikasi dengan baik atau mengungkapkan pendapat dan cara berpikirnya secara lisan maupun tulisan dengan jelas, serta berpotensi memenuhi karakteristik kemampuan penalaran matematis. Siswa yang terpilih sebagai subjek penelitian adalah sebagai berikut.

Tabel 2. Subjek Utama Penelitian

\begin{tabular}{|c|l|c|c|c|c|c|}
\hline \multirow{2}{*}{ NO } & \multirow{2}{*}{ NAMA } & \multirow{2}{*}{ L/P } & \multicolumn{2}{|c|}{ GEFT } & \multicolumn{2}{c|}{$\begin{array}{c}\text { Kemampuan Awal } \\
\text { Siswa }\end{array}$} \\
\cline { 4 - 7 } & & & Nilai & Kategori & Nilai & Kategori \\
\hline 1 & FIT1 & P & 13 & FI & 98 & Tinggi \\
\hline 2 & FIT2 & L & 10 & FI & 97 & Tinggi \\
\hline 3 & FDT1 & L & 9 & FD & 92 & Tinggi \\
\hline 4 & FDT2 & P & 8 & FD & 88 & Tinggi \\
\hline 5 & FIR1 & P & 10 & FI & 73 & Rendah \\
\hline 6 & FIR2 & P & 12 & FI & 73 & Rendah \\
\hline
\end{tabular}




\begin{tabular}{|l|l|l|l|l|l|l|}
\hline 7 & FDR1 & P & 6 & FD & 71 & Rendah \\
\hline 8 & FDR2 & P & 9 & FD & 71 & Rendah \\
\hline
\end{tabular}

Ket. $\quad \mathrm{L}=$ Laki-laki

$\mathrm{P}=$ Perempuan

Adapun hasil penelitiannya adalah:

\section{Subjek FIT}

a. Pada subjek ini dapat menyajikan peryataan matematika secara lisan, tertulis atau gambar.

b. Dapat mengajukan dugaan dalam menyelesaikan soal cerita.

c. Dapat melakukan manipulasi matematika untuk memperoleh jawaban.

d. Dapat menyusun bukti dan memberikan alasan terhadap kebenaran solusi.

e. Dapat menarik kesimpulan di akhir pengerjaan.

f. Dapat memeriksa kesahihan suatu argumen sebelum mengumpulkan lembar jawaban.

\section{Subjek FDT}

a. Subjek ini secara umum dapat menyajikan peryataan matematika secara lisan, tertulis atau gambar.

b. Secara umum dapat mengajukan dugaan dalam menyelesaikan soal cerita.

c. Dapat melakukan manipulasi matematika untuk memperoleh jawaban.

d. Dapat menyusun bukti dan memberikan alasan terhadap kebenaran solusi. Namun subjek kurang jelas dalam membuktikan soal nomor 2 dan untuk menguatkan pernyataan subjek memberikan contoh.

e. Dapat menarik kesimpulan di akhir pengerjaan.

f. Dapat memeriksa kesahihan suatu argumen sebelum mengumpulkan lembar jawaban.

\section{Subjek FIR}

a. Subjek ini secara umum dapat menyajikan peryataan matematika secara lisan, tertulis atau gambar.

b. Secara umum dapat mengajukan dugaan dalam menyelesaikan soal cerita.

c. Dapat melakukan manipulasi matematika untuk memperoleh jawaban.

d. Dapat menyusun bukti dan memberikan alasan terhadap kebenaran solusi. Namun subjek tidak dapat membuktikan soal nomor dua. Subjek hanya dapat menunjukkan bahwa pernyataannya benar melalui contoh yang dibuat oleh subjek.

e. Dapat menarik kesimpulan di akhir pengerjaan. Namun kesimpulan yang diberikan tidak lengkap.

f. Subjek kurang dapat memeriksa kesahihan suatu karena subjek belum bisa menyelesaikan soal nomor dua dengan benar.

\section{Subjek FDR}

Kemampuan penalaran subjek FDR untuk setiap indikator masih kurang karena subjek tidak bisa mengerjakan soal nomor dua. 
Selanjutnya akan dibahas hasil penelitian yang mengacu pada hasil kerja terhadap tes kemampuan penalaran matematis oleh subjek kelompok siswa dengan kemampuan awal tinggi (KT) ,kelompok siswa dengan kemampuan awal rendah (KR), kelompok siswa dengan gaya kognitif field independent (FI) dan kelompok siswa dengan gaya kognitif field dependent (FD). Pada bagian ini juga akan dibahas mengenai persamaan dan perbedaan diantaranya serta temuantemuan dari hasil penelitian.

Tabel 3. Deskripsi Kemampuan Penalaran Matematis Subjek FIT, FIR, FDT dan FDR

\begin{tabular}{lcc}
\hline & KT & KR \\
\hline FI & Subjek FIT & Subjek FIR
\end{tabular}

1. Subjek FIT dapat menyajikan peryataan matematika secara lisan, tertulis atau gambar dengan menuliskan unsur yang diketahui dan ditanyakan serta menyajikan apa yang diketahui dalam bentuk gambar untuk mempermudah proses penyelesaian.

2. Subjek FIT dapat mengajukan dugaan dengan melakukan dugaan awal sebelum mengerjakan soal serta dapat menduga panjang sisi yang belum diketahui dalam soal.

3. Subjek FIT dapat melakukan manipulasi matematika dengan mengingat konsep sebelumnya dari permasalahan yang diberikan.

4. Subjek FIT dapat menyusun bukti dan memberikan alasan terhadap kebenaran solusi dengan menggunakan rumus-rumus luas bangun datar.

5. Subjek FIT dapat menarik kesimpulan di akhir jawaban subjek.

6. Subjek FIT dapat memeriksa kembali kesahihan suatu argumen tanpa menggunakan coret-coretan.
1. Subjek FIR dapat menyajikan peryataan matematika secara lisan, tertulis atau gambar dengan menuliskan unsur yang diketahui dan ditanyakan serta menyajikan apa yang diketahui dalam bentuk gambar untuk mempermudah proses penyelesaian.

2. Subjek FIR dapat mengajukan dugaan dengan melakukan dugaan awal sebelum mengerjakan soal serta dapat menduga panjang sisi yang belum diketahui dalam soal.

3. Subjek FIR dapat melakukan manipulasi matematika dengan mengingat konsep sebelumnya dari permasalahan yang diberikan.

4. Subjek FIR kurang dapat menyusun bukti dan memberikan alasan terhadap kebenaran solusi karena pada soal nomor 2 subjek tidak dapat membuktikan bahwa pernyataannya benar. Subjek hanya dapat menunjukkan bahwa pernyataannya benar melalui contoh soal yang dibuat oleh subjek.

5. Subjek FIR kurang dapat menarik kesimpulan di akhir jawaban karena cara subjek menyimpulkan masih kurang lengkap. 
6. Subjek FIR kurang dapat memeriksa kembali kesahihan suatu argumen karena jawaban nomor 2 subjek kurang tepat.

\section{FD Subjek FDT}

1. Subjek FDT dapat menyajikan peryataan matematika secara lisan, tertulis atau gambar dengan menuliskan unsur yang diketahui dan ditanyakan serta menyajikan apa yang diketahui dalam bentuk gambar untuk mempermudah proses penyelesaian.

2. Subjek FDT dapat mengajukan dugaan dengan melakukan dugaan awal sebelum mengerjakan soal.

3. Subjek FDT dapat melakukan manipulasi matematika dengan mengingat konsep sebelumnya dari permasalahan yang diberikan.

4. Subjek FDT kurang dapat menyusun bukti dan memberikan alasan terhadap kebenaran solusi karena pada soal nomor 2 subjek kurang jelas dalam membuktikan bahwa pernyataannya benar.

Sehingga subjek butuh memperkuat pernyataannya melalui contoh soal yang dibuat oleh subjek.

5. Subjek FDT dapat menarik kesimpulan di akhir jawaban subjek.

6. Subjek FDT dapat memeriksa kembali kesahihan suatu argumen tanpa menggunakan coret-coretan.
1. Subjek FDR kurang dapat menyajikan peryataan matematika secara lisan, tertulis atau gambar karena subjek tidak dapat menyajikan peryataan matematika secara lisan, tertulis atau gambar pada soal nomor 2 .

2. Subjek FDR kurang dapat mengajukan dugaan karena subjek tidak dapat mengajukan dugaan pada soal nomor 2 .

3. Subjek FDR kurang dapat melakukan manipulasi matematika karena subjek tidak dapat melakukan manipulasi matematika pada soal nomor 2 .

4. Subjek FDR kurang dapat menyusun bukti dan memberikan alasan terhadap kebenaran solusi karena pada soal nomor 2 subjek tidak dapat menyelesaikan dengan benar.

5. Subjek FDR kurang dapat menarik kesimpulan di akhir jawaban karena subjek tidak dapat menarik kesimpulan di akhir jawaban pada soal nomor 2 .

6. Subjek FDR kurang dapat memeriksa kembali kesahihan suatu argumen karena subjek tidak bisa menyelesaikan soal nomor 2 dengan tepat.

Berdasarkan tabel di atas dapat dilihat perbedaan kemampuan penalaran matematis antara subjek FIT, subjek FIR, subjek FDT dan subjek FDR. Subjek FIT dapat mencapai 6 indikator dengan baik dari 6 indikator yang ditentukan. Subjek FIR dapat mencapai 3 indikator dengan baik dari 6 indikator yang ditentukan. Subjek FIR kurang dapat menyusun bukti dan memberikan alasan terhadap kebenaran solusi, menarik kesimpulan, dan memeriksa kesahihan suatu argument. Subjek FDT dapat mencapai 5 indikator dengan baik dari 6 indikator 
yang ditentukan. Subjek FDT kurang dapat menyusun bukti dan memberikan alasan terhadap kebenaran solusi. Subjek FDR memiliki kemampuan penalaran yang kurang untuk semua indikator kemampuan penalaran.

\section{SIMPULAN DAN SARAN}

\section{Simpulan}

Terdapat perbedaan karakteristik penalaran matematis siswa dalam memahami materi segiempat ditinjau dari gaya kognitif dan kemampuan awal siswa sebagai berikut:

1. Subjek gaya kognitif FI berkemampuan awal tinggi dalam melakukan penalaran memiliki tingkat penalaran yang baik. Subjek ini dapat memahami masalah dengan baik, menyusun rencana penyelesaian, melakukan rencana penyelesaian sesuai dengan langkah-langkah penyelesaian yang teliti dan sistematis, serta melihat kembali jawaban kemudian memeriksanya tanpa menggunakan coretan-coretan. Subjek ini memiliki semua indikator kemampuan penalaran yang sudah ditetapkan dalam penelitian ini yaitu (1) Menyajikan pernyataan matematika secara lisan, tertulis atau gambar. (2) Mengajukan dugaan. (3) Melakukan manipulasi matematika. (4) Menyusun bukti dan memberikan alasan terhadap kebenaran solusi. (5) Menarik simpulan dari pernyataan. (6) Memeriksa kesahihan suatu argumen.

2. Subjek gaya kognitif FD berkemampuan awal tinggi dalam melakukan penalaran memiliki tingkat penalaran berbeda dengan subjek gaya kognitif FI berkemampuan awal tinggi dimana subjek FD sulit memahami struktur dalam memahami masalah dan menyelesaikan masalah serta membutuhkan insruksi berupa penguatan. Subjek ini memiliki semua indikator kemampuan penalaran yang sudah ditetapkan dalam penelitian ini yaitu (1) Menyajikan pernyataan matematika secara lisan, tertulis atau gambar. (2) Mengajukan dugaan. (3) Melakukan manipulasi matematika. (4) Menyusun bukti dan memberikan alasan terhadap kebenaran solusi. (5) Menarik simpulan dari pernyataan. (6) Memeriksa kesahihan suatu argumen. Akan tetapi indikator menyusun bukti dan memberikan alasan terhadap kebenaran solusi yang dimiliki subjek masih kurang baik. Hal ini dapat dilihat dari penulisan jawaban subjek kurang sistematis.

3. Subjek gaya kognitif FI berkemampuan awal rendah dalam melakukan penalaran memiliki tingkat penalaran yang baik dalam memahami masalah, menyusun rencana penyelesaian. Akan tetapi memiliki tingkat penalaran yang kurang dalam melakukan rencana penyelesaian, seperti adanya dugaan yang tidak bisa dibuktikan dengan jelas, tetapi subjek hanya bisa menunjukkan bahwa dugaannya itu benar. Subjek ini memiliki semua indikator kemampuan penalaran yang sudah ditetapkan dalam penelitian ini yaitu (1) Menyajikan pernyataan matematika secara lisan, tertulis atau gambar. (2) Mengajukan dugaan. (3) Melakukan manipulasi matematika. (4) Menyusun bukti dan memberikan alasan terhadap kebenaran solusi. (5) Menarik simpulan dari pernyataan. (6) Memeriksa kesahihan suatu argumen. Akan tetapi indikator 
menyusun bukti dan memberikan alasan terhadap kebenaran solusi, menarik simpulan dari pernyataan dan memeriksa kesahihan suatu argumen yang dimiliki subjek masih kurang baik. Hal ini dapat dilihat dari cara subjek melakukan rencana penyelesaian dan melihat kembali.

4. Subjek gaya kognitif FD berkemampuan awal rendah dalam melakukan penalaran memiliki tingkat penalaran kurang dalam memahami dan menyelesaikan masalah karena subjek melakukan kesalahan dalam mengerjakan soal dan dalam menulis jawaban banyak yang tidak dilengkapi dengan rumus umum. Selain itu soal nomor 02 tidak bisa dikerjakan oleh subjek.

\section{Saran}

1. Bagi siswa diharapkan mampu menyelesaikan masalah khususnya pada materi soal cerita segiempat menggunakan kemampuan bernalarnya dan solusi penyelesaian dalam menyelesaikan masalah soal cerita melalui manipulasi matematika.

2. Bagi guru-guru khususnya guru matematika diharapkan mampu memberikan pengajaran yang membuat siswa tidak hanya menghafal cara penyelesaian dari setiap soal cerita segiempat, tetapi juga mampu menalarkan konsepkonsep segiempat dengan menyajikan soal-soal non-rutin yang mengungkapkan kemampuan bernalar dari setiap siswa. Serta diharapkan guru bisa menggunakan model, pendekatan, metode maupun strategi pembelajaran tertentu dalam mengembangkan kemampuan penalaran setiap siswa.

3. Untuk penelitian yang relevan, agar meneliti kembali kemampuan penalaran yang lebih lengkap dibutuhkan verifikasi dengan (a) menghubungkan beberapa materi soal cerita segiempat yang dikaitkan dengan materi-materi lainnya, (b) indikator-indikator kemampuan penalaran secara lengkap yang dikaitkan dengan apa yang dipikirkan subjek penelitian.

\section{DAFTAR PUSTAKA}

Darmono, A. 2012. "Identifikasi Gaya Kognitif (Cognitive Style) Peserta Didik dalam Belajar", Paper Presented at Sekolah Tinggi Agama Islam Ngawi, (online),(http://ejournal.iaingawi.ac.id/index.php/almabsut/article/view/3

9, Diakses 21 Februari 2018).

Muharom, Tria. 2014. Pengaruh Pembelajaran dengan Model Tipe Students Teams Achivement Division (STAD) Terhadap Kemampuan Penalaran dan Komunikasi Matematis Peserta Didik di SMK Negeri Manonjaya Kabupaten Tasikmalaya.Jurnal Pendidikan dan Keguruan, (online), Volume $11 \quad$ No 1 , (http://pasca.ut.ac.id/journal/index.php/JPK/article/view/2/2, Diakses 21 Februari 2018)

Mulbar, Usman. 2012. Pengembangan Perangkat Pembelajaran Matematika Realistik di Sekolah Menengah Pertama. Jurnal Sainsmat, (online), Vol. I, No. (http://download.portalgaruda.org/article.php?article $=57588 \& v a l=4331 \&$ title $=$ Pengembangan $\% 20$ Perangkat $\% 20$ Pembelajaran $\% 20$ Matematika $\% 2$ 
ORealistik\%20di\%20Sekolah\%20Menengah\%20Pertama, Diakses 16 Agustus 2018)

Mulbar, Usman, Abdul Rahman \& Ansari S. Ahmar. 2017. Analysis of the ability in mathematical problem-solving based on SOLO taxonomy and cognitive style. World Transactions on Engineering and Technology Education (online), Vol.15, No.1

(http://www.wiete.com.au/journals/WTE\&TE/Pages/Vol.15,\%20No.1\%2 0(2017)/12-Ahmar-AS.pdf, Diakses 16 Agustus 2018)

Permana, Yanto, \& Utari Sumarmo. 2007. Mengembangkan Kemampuan Penalaran dan Koneksi Matematik Siswa SMP Melalui Pembelajaran Berbasis Masalah.Educationist. Jurnal Pendidikan Matematika, (online), 1 116-123, (https://s3.amazonaws.com/academia.edu.documents/19108312/6 yanto permana layout2rev.pdf?AWSAccessKeyId=AKIAIWOWYYGZ2Y53U $\underline{\text { L3A\&Expires }=1521862024 \& \text { Signature }=1 \text { AQxrgmvBQCTLsxNKP9HDIt }}$ VHBI\%3D\&response-contentdisposition=inline\%3B\%20filename\%3DPengembangan_Kemampuan_P enalaran_dan_Kon.pdf, Diakses 21 Februari 2018)

Schunk, Dale H., 2012, Learning Theories An Educational Perspektive. Yogyakarta: Pustaka Pelajar

Shadiq, Fadjar. 2004. Pemecahan Masalah, Penalaran, dan Komunikasi. Makalah disampaikan pada Diklat Instruktur/Pengembang Matematika SMA Jenjang Dasar di PPPG Matematika Tanggal 6 s.d. 19 Agustus 2004. Yogyakarta: Depdiknas Dirjendiknas Dasar dan Menengah Pusat Pengembangan Penataran Guru (PPPG) Matematika Yogyakarta.

Susanto, Herry Agus. 2008. Mahasiswa Field Independent dan Field Dependent Dalam Memahami Konsep Grup . Seminar Matematika dan Pendidikan Matematika tanggal 28 Nopember 2008, (online).( http://eprints.uny.ac.id/6902/1/P5\%20Pendidikan\%20\%28Herry\%20AS \%29.pdf, Diakses 22 Februari 2018)

Usman, Moh.Uzer dan Lilis Setiawati. 1993. Upaya Optimalisasi Kegiatan Belajar Mengajar. Bandung:PT.Remaja Rosdakarya.

Wati, Erna Hartika. 2016. Kesalahan Siswa SMP dalam Menyelesaikan Soal Matematika Berbasis PISA pada Konten Change and Relationship. Artikel Publikasi Ilmiah (online). (https://publikasiilmiah.ums.ac.id/bitstream/handle/11617/6959/21_77_ Makalah\%20Rev\%20Erna\%20Hartika\%20Wati.pdf;sequence=1, Diakses 20 Februari 2018) 